\title{
When the Perpetrator becomes a Reliable Witness of the Holocaust: On Jonathan Littell's Les Bienveillantes
}

\section{Citation}

Suleiman, Susan Rubin. 2009. When the perpetrator becomes a reliable witness of the Holocaust: On Jonathan Littell's Les bienveillantes. New German Critique 36(1): 1-19.

\section{Published Version}

doi:10.1215/0094033X-2008-018

\section{Permanent link}

http://nrs.harvard.edu/urn-3:HUL.InstRepos:5345309

\section{Terms of Use}

This article was downloaded from Harvard University's DASH repository, and is made available under the terms and conditions applicable to Other Posted Material, as set forth at http:// nrs.harvard.edu/urn-3:HUL.InstRepos:dash.current.terms-of-use\#LAA

\section{Share Your Story}

The Harvard community has made this article openly available. Please share how this access benefits you. Submit a story.

Accessibility 


\section{When the Perpetrator Becomes a Reliable Witness of the Holocaust: On Jonathan Littell's Les bienveillantes}

\section{Susan Rubin Suleiman}

Victims of the Holocaust have for a long time fascinated historians, psychologists, and novelists, as well as the general public; many victims themselves have published testimonies or autobiographical fictions, attesting to the ongoing interest in the experience of those who suffered at the hands of the Nazis. Perpetrators' testimonies, however, are virtually nonexistent; that of Rudolf Höss, the commandant of Auschwitz, who wrote his "memoirs" in prison before being executed, is a rare exception. Anyone curious about the actions and motivations of those who willingly participated in the Nazi project of mass murder has had to rely on historians and philosophers such as Raul Hilberg, Hannah Arendt, Christopher Browning, and Daniel Goldhagen.

Fictional representations of the inner world of perpetrators (as opposed to the standard external view of Nazi villains in countless films) are also hard to find. Robert Merle's novel La mort est mon métier (Death Is My Trade, 1952), a fictionalized version of Höss's autobiography, was until recently the only full-length novel narrated in the voice of a Nazi perpetrator. Jorge Luis Borges's short story “Ein Deutsches Requiem” (“A German Requiem," 1949) is the unrepentant monologue of a Nazi officer about to be executed, and George Steiner concludes his novel The Portage to San Cristobal of A. H. (1981) with a first-person self-justificatory rant by Adolf Hitler himself. David Grossman's 
novel See Under: Love (1989) devotes some brilliant pages to the inner life of the camp commandant Neigel, obviously modeled on Treblinka's real-life commandant, Franz Stangl; Martin Amis's novel Time's Arrow (1991) is the postwar narrative of a Nazi doctor, but told in reverse order, as if to deny not only what happened but also any sense of responsibility on the part of the protagonist-narrator. A few fiction films have also attempted to suggest, if not downright represent, the subjectivity of perpetrators. One thinks of the "mirror-scene" depicting the sadistic camp commander Amon Goeth in a moment of self-doubt in Steven Spielberg's film Schindler's List (1993), or of Oliver Hirschbiegel's more extended recent attempt to portray Joseph Goebbels and Hitler as full-fledged characters in Der Untergang (Downfall, 2004), but again, these are exceptions rather than the rule.

One can understand the reluctance of serious fiction writers to portray a Nazi perpetrator's inner life. The extended representation of a character's subjectivity - not only actions but feelings, perceptions, opinions, and way of being in the world-necessarily requires a degree of empathy, on the part of both author and reader; even if the character is loathsome, he or she must at least be recognized as human, hence sharing some characteristics with the rest of us. But empathy for a perpetrator of genocide-even if it coexists with revulsion and moral condemnation - puts both author and reader on uncomfortable ethical ground, and on uncomfortable aesthetic ground as well. How might one portray a Nazi murderer as the protagonist of a novel, at once recognizably human, or even familiar, and morally inexcusable? Should such a protagonist be allowed the privilege of the narrative voice, given the almost automatic call to empathy that accompanies first-person narrative? On the other hand, how could one possibly adopt the voice of an "omniscient" narrator in exploring the behavior and perceptions of such a protagonist? These are merely the first and most obvious aesthetic questions that confront any writer hardy enough (or reckless enough) to undertake the enterprise of portraying a perpetrator of the Holocaust "from within."

These questions lead me directly to Jonathan Littell's nine-hundredpage novel, Les bienveillantes (The Kindly Ones), published in France in September 2006 and soon to appear in English. ${ }^{2}$ Purporting to be the first-

1. I have in mind, of course, a serious writer with a sense of integrity; the garbage that may appear on negationist Web sites-if indeed the latter carry pieces of fiction that admit to being fiction-would be a totally different object of study.

2. Jonathan Littell, Les bienveillantes (Paris: Gallimard, 2006). Hereafter cited by page number. All translations from the French in this essay are my own. 
person narrative of a former SS officer writing many years after World War II, Les bienveillantes became the biggest best seller of the year and won the most prestigious French literary prize, the Prix Goncourt, as well as the Grand Prix of the French Academy. ${ }^{3}$ The author, a thirty-eight-year-old American who had lived in France for a good part of his childhood and adolescence, wrote the book in French. (His father, Robert Littell, is a best-selling writer of detective novels.) Its critical reception in France, as elsewhere, has been sharply divided, notably in Germany, where it appeared in spring 2008 to wildly mixed reviews, as reported by Klaus Theweleit in this issue of New German Critique: some readers find the book brilliant, while others excoriate it. Two "total raves" in the weekly Le nouvel observateur (by Jérôme Garcin and Dominique Fernandez), published right when the book appeared, both compared Littell to Leo Tolstoy, among other literary giants; a few weeks later, in the same magazine, Claude Lanzmann paid the novel a grudging compliment as far as historical accuracy was concerned but then condemned it for its lack of verisimilitude, its sensationalist "fascination with horror," and other literary sins. ${ }^{4}$ Many others weighed in as well, with equally divergent opinions: the book critic Samuel Blumenfeld, writing in Le monde, compared Littell to Tolstoy, Boris Pasternak, and Fyodor Dostoyevsky; the historian Peter Schöttler (who is German), also writing in Le monde, dismissed Littell's novel as devoid of historical verisimilitude, a sensationalist exploitation that reduces "the complex phenomenon of the Shoah" to sadism and perversion. ${ }^{5}$ Adding a touch of silliness to the negative critiques, the academician Marc Fumaroli decreed that Littell's sin was not recognizing what "naturally belongs" to French literature: "He transports into our language an epic and apocalyptic category of the imagination that is not natural to us, but that is natural to the Americans." ${ }^{\prime 6}$ Meanwhile, on the Internet, bloggers discussed a book titled Les malveillantes (The Unkindly Ones), which came out a couple of months after Littell's book and purported to show all that was wrong with it. The general feeling among bloggers was that the author of this work, a certain

3. According to news accounts, the book sold 170,000 copies during the first month after publication; after the prizes, total sales went up to over 600,000 .

4. Jérôme Garcin, "Littell est grand," Le nouvel observateur, August 24-30, 2006, 48-51; Dominique Fernandez, "Un nouveau Guerre et Paix," Le nouvel observateur, August 24-30, 2006, 51; Claude Lanzmann, "Lanzmann juge Les Bienveillantes," Le nouvel observateur, September 21-27, 2006, 14.

5. Samuel Blumenfeld, "Frères humains ...," Le monde, September 1, 2006; Peter Schöttler, "Tom Ripley au pays de la Shoah," Le monde, October 14, 2006.

6. Marc Fumaroli, "Une tout autre 'exception française,", Le monde, October 27, 2006. 
Paul-Eric Blanrue, was suffering from sour grapes and trying to cash in on another man's success. ${ }^{7}$

A huge commercial success, then, and a huge artistic success as well, according to some; a piece of overblown American kitsch, according to others. ${ }^{8}$ I count myself among the book's admirers. While it has some problematic aspects, it is, I believe, an extraordinarily interesting and original work. What makes it so? As all of its critics, both positive and negative, recognized, the novel's most outstanding feature (other than its length) is that the story is told, retrospectively, by a first-person narrator who was a young, highly placed SS officer, not to mention an intellectual and a doctor of jurisprudence, bilingual in French and German, who escaped from Berlin to France at the end of the war and has been living there under an assumed identity ever since. ${ }^{9}$ Furthermore, he announces from the outset that he "regrets nothing" and that his account is not going to be a hypocritical expression of repentance (12-13). His opening sentence, with its allusion to François Villon's "Le Testament""Frères humains, laissez-moi vous raconter comment ça s'est passé" (Brother humans, let me tell you how it happened) (11) -indicates both his love of French literature and one of his ongoing themes: he and the Nazis were not outside "the human" but within it. Under different circumstances, his readers could well have done what he did: "Allons, puisque je vous dis que je suis comme vous" (Go on, since I tell you that I am like you), is how he ends his introductory chapter (30).

The question is, what do we make of this? Is Maximilien Aue a Nazi out of some third-rate Hollywood film, mouthing the usual rationalizations and justifications ("You too could have done what I did"), while Littell uses

7. See the Web site buzz.litteraire.free.fr. The number of blog entries on Littell's novel is extraordinary, from those of "ordinary" readers (one blogger who identifies herself as a young woman and teacher kept a running diary of her reading of the novel over a period of several months: www.lalettrine.com) to those of professionals like the writer Pierre Assouline, who publishes a daily blog for Le monde (passouline.blog.lemonde.fr). A sampling of blogs suggests that the great majority of "internautes" are enthusiastic about the book.

8. Among the positives, the March 2007 issue of Le débat, whose editor in chief is Pierre Nora, one of the book's great admirers (and an editor at Gallimard, the book's publisher), contains several excellent articles as well as two long interviews with Littell; this issue appeared after I had written most of the present essay, and I am pleased to note that the contributors share some of my own views.

9. It is left ambiguous exactly when the narrator-who we learn was born in 1913-is writing this "memoir." He states in his introduction that he is still professionally active at the time of writing as the head of a lace factory in northern France, which suggests that he cannot be writing "now," after 2000. He refers to the work of Raul Hilberg, whose book The Destruction of the European Jews first appeared in 1961 but became more widely known only in the 1980s. This could place the time of writing between the 1960s and the 1980s. 
him to indulge in sensationalist descriptions of horror? ${ }^{10}$ I forgot to mention that Aue was, in his youth, the incestuous lover of his twin sister, as well as a homosexual with a "perverse" imagination and a matricide! Or is Littell doing something really new and important here, something that deserves careful consideration and discussion?

Littell has stated that he began with the idea of inventing an ex-Nazi as his narrator because "perpetrators never speak. Silence is their essence." 11 This is not literally true as concerns the Holocaust, because there do exist a few memoirs or reminiscences by former Nazis. ${ }^{12}$ But Littell is right in a broader sense: we have never yet seen a comprehensive account of Nazi atrocities during World War II that is told entirely from the perspective, and in the voice, of a perpetrator. Littell's Aue has qualities that only a fictional character can have: he is present, as an observing participant, in just about every place where the worst crimes against humanity were committed; he has access to privileged information available only to the inner circle around the SS leader Heinrich Himmler; and most important, he possesses the intelligence and analytic ability, the emotional detachment and temporal distance, as well as a certain moral sensibility, to act as a reliable historical witness. The combination of participant status as a perpetrator with historical reliability, and with what I call moral witnessing, which Aue possesses, is a new phenomenon in fiction. The more intelligent of the negative critiques emphasize that this combination is implausible according to realist criteria, and problematic in other ways as well. Indeed, whether one admires Les bienveillantes or loathes it depends largely on how one responds to the improbable combination of perpetrator and reliable witness that Aue represents. I will therefore focus on that question, then raise what I consider a problematic aspect of Littell's novel.

\section{The Perpetrator as Reliable Historical Witness}

Les bienveillantes consists of seven unnumbered chapters of varying lengths, whose titles correspond to the movements of a baroque dance suite: "Toccata,"

10. For a typical negative judgment of this sort, see Jean Clair, "Une apocalypse kitsch," Commentaire, February 2007, 1106-7. Clair, like several other negative critics, indulges in some fairly obvious anti-American rhetoric.

11. Reported by Garcin, "Littell est grand," 50 . Littell made this observation in other interviews as well, for example, in one with Samuel Blumenfeld, "Jonathan Littell: 'La parole vraie d'un bourreau n'existe pas," Le monde, September 1, 2006.

12. Besides Höss's book, we have Franz Stangl's reminiscences as told to Gitta Sereny, in her remarkable book Into That Darkness (New York: McGraw-Hill, 1974), and Albert Speer's memoirs and diaries. 
"Allemandes," “Courante," "Sarabande," "Menuet," “Air," and "Gigue."13 This may be a reference to the narrator's declared love of François Couperin and Jean-Philippe Rameau, but it also evokes Louis-Ferdinand Céline's Rigodon, which similarly uses a dance metaphor to describe the madness of World War II. The two longest sections, ironically titled "Allemandes" and "Menuet" (slow and stately dances), constitute the novel's historical and moral center and are also the ones that deal most explicitly and in great detail with the Holocaust. "Allemandes I et II," the nearly three-hundred-page chapter that immediately follows the introductory "Toccata," focuses on the mass killings of Jews in the Ukraine and elsewhere in the Soviet Union between the German invasion of June 1941 and the German defeat at Stalingrad in February 1943. "Menuet (en rondeaux)," the three-hundred-page fifth chapter, offers a detailed account of the extermination camps in Poland, as observed by the narrator roughly between the spring of 1943, when he first visits Sobibor, Auschwitz, and other camps, to the "death marches" that preceded the Soviet entry into Auschwitz in January 1945. Littell's choice of locations indicates his ambition, for these two spheres of activity-the killings by the Einsatzgruppen (mobile killing units) in the Soviet Union, and the system of the extermination camps in Poland - can be said to constitute the essence of the historical event we know as the Holocaust.

What I mean by "the perpetrator as reliable historical witness" can be made clear by a few examples. The first Aktion against the Jews that Aue witnesses takes place in a Ukrainian forest in July 1941. The text emphasizes that he is not one of the killers or one of those in charge: "Janssen me proposa de venir assister à une action" (Janssen suggested that I go to see an action) (81). Janssen is the commanding SS officer, while Aue is there to watch. The fictional Aue, like the historical SS in the Einsatzgruppen, is a member of the Sicherheitsdienst (SD), the security police arm of the SS, whose job was to follow the German Army's advance and eliminate "dangerous elements" like Jews and Communists; but Littell makes Aue's job principally one of intelligence gathering, so his activity consists largely in observing and writing reports. This does not exonerate him, of course, since he is a willing if somewhat passive participant in the mass murders, which he considers "inévita-

13. The toccata, a piece of free improvisation, often preceded the actual dance movements in a suite. Here it corresponds to the narrator's introduction and "address to the reader" before he begins his account of events in World War II. Littell discusses the novel's musical structure in his long conversation with the novelist Richard Millet (his editor at Gallimard), "Conversation à Beyrouth," Le débat, March 2007, 9-11. 
bles et nécessaires" (inevitable and necessary) (82). And as he himself tells his sister much later, "Je considère que regarder engage autant de responsabilité que faire" (I believe that looking involves as much responsibility as doing) (445). Nevertheless, by having Aue observe rather than command or do the killing, Littell places him at a small but crucial distance from what he describes.

What does Aue see in the forest? SS officers have rounded up a group of Jewish men and are ordering them to dig ditches into which they will be shot. At this point, only Jewish men were rounded up as "dangerous"; a few weeks later, women and children would be as well. It is not easy to find a good spot for the ditches, partly because there are already other ditches full of corpses, presumably shot by the Bolsheviks. The scene becomes grotesquely comical, as well as horrifying, as those about to be executed and their executioners traipse around looking for a free spot, while the commanding officer sputters in frustration. The whole process, described at length by Aue, turns out to be improvised and "amateurish": blood and brains splatter all over; some people have to be shot twice; the ditches the victims finally dig turn out to be full of water, so their bodies float rather than sink after they are shot. Aue describes all this, then comments:

Un tel amateurisme devint vite l'exception. Au fil des semaines, les officiers acquéraient de l'expérience, les soldats s'habituaient aux procédures; en même temps, on voyait bien que tous cherchaient leur place dans tout ça, réfléchissaient à ce qui se passait, chacun à sa manière. A table, le soir, les hommes discutaient des actions, se racontaient des anecdotes. ... Certains réagissaient par la brutalité, parfois le sadisme. . . . Nos hommes, très souvent, photographiaient les exécutions.

[Such amateurism soon became the exception. As the weeks went by, the officers gained more experience and the soldiers became used to the procedures; at the same time, one could see that they all wondered about their place in all this and thought about what was going on, each in his own way. In the evening over dinner, the men talked about the "actions," told anecdotes.... Some reacted with brutality, at times with sadism. ... Very often, our men photographed the executions.] (88)

In this commentary, Aue's role as a historical witness becomes fully apparent. The wide-angle description ("some did this, others did that"), as well as the reference to photographs being taken, is clearly based on retrospective historical knowledge; this is one example of how Littell "endows his SS . . 
with History as memory," as Lanzmann puts it. ${ }^{14}$ Lanzmann finds this a flaw in the novel, even though one could rationalize it on the grounds that Aue consulted many history books before writing his memoir, as he tells us in his introduction. But even Aue's immediate reactions as he watches the shootings seem closer to those of a present-day observer than to someone on the spot. Looking at the Ukrainian auxiliaries ordered to do the shooting, he thinks to himself:

La plupart d'entre eux s'étaient battus contre les Polonais, puis contre les Soviétiques, ils devaient avoir rêvé d'un avenir meilleur, pour eux et pour leurs enfants, et voilà que maintenant ils se retrouvaient dans une forêt, portant un uniforme étranger et tuant des gens qui ne leur avaient rien fait, sans raison qu'ils puissent comprendre. Que pouvaient-ils penser de cela? Pourtant, lorsqu'on leur en donnait l'ordre, ils tiraient. . . Q Que penseraientils de tout cela plus tard?

[Most of them had fought against the Poles, then against the Soviets; they must have dreamed of a better future for themselves and their children, and here they were in a forest, wearing a foreign uniform and killing people who hadn't done them any harm, for no reason they could comprehend. What could they be thinking about that? Yet, when they were given the order, they pulled the trigger. ... What would they think of all that later?] (87)

This kind of reflection-together with the historical information contained in these few sentences about Ukrainians enrolled in the German army during the invasion of Russia and used in the murder of Jews-is clearly retrospective, even though it seems to be occurring at the moment; the use of free indirect discourse to report Aue's thoughts marks a temporal and cognitive gap between the narrator and his former self. As some of the negative critics have pointed out, such "clear-sighted" knowledge and reflection lack verisimilitude, even on the part of an intellectual member of the SS at that time. It is one example of what Lanzmann calls, very critically, the narrator's "ventriloquism of history books." ${ }^{15}$

Contrary to Lanzmann, I find this kind of disguised retrospection (or we could call it anachronistic narration) to be one of this novel's greatest successes, and a highly original invention. Littell, in making his SS narrator into a reliable historical witness - that is, one who functions as a witness

14. Lanzmann, "Lanzmann juge Les Bienveillantes."

15. Ibid. 
informed by retrospective historical knowledge-accomplishes something completely new. For here the historical truth-which includes not only the facts but also an attempt to grapple with their ethical and psychological implications-comes out of the mouth of one who was part of the very system responsible for the horrors he is recounting, a system whose functioning he describes in detail. This procedure, which lacks plausibility historically, is extremely effective as fiction. Littell's contemporary readers cannot simply read Aue's narrative as an unmediated account; as I read, I am aware of the author behind the narrator and of the literary choices he is making. Seeing things this way introduces a degree of "derealization" into the narrative, since we are aware of the author's manipulations, the way we might be aware of the camera's movements in a film. But I see this derealization as adding a metanarrative dimension to the novel's realism, marking this novel as a postmodern work rather than a classically realist one.

Lanzmann uses the idea of derealization in a different sense, as yet another flaw in this novel. According to him, Littell "derealizes" the horrors he describes by rendering them in overwhelming detail; similarly, other critics accuse Littell of wallowing in these atrocities ${ }^{16}$ But it is precisely the leisurely accumulation of details, including the killings and the killers' thoughts and speculations, that distinguishes a novel from a work of history. Hilberg's magnum opus, The Destruction of the European Jews, is a work of history that Littell cites as a major inspiration. ${ }^{17}$ But it is a different kind of writing. Lanzmann worries that readers might prefer Littell's book to Hilberg's. But if Littell's account is a "ventriloquism of history books," as Lanzmann also claims, his worry should be somewhat lessened. Nor can we assume that those who don't read Littell will read Hilberg instead.

Consider Littell's account of the massacre at Babi Yar. This event, which took place September 29-30, 1941, in Kiev, has been memorialized in poetry and fiction (e.g., Yevgeny Yevtushenko's “Babi Yar,” D. M. Thomas's White Hotel) as well as in history books. In Littell's version, we get an extremely detailed account of the preparations for this "Grosse Aktion" (large-scale action), where everything is thought out in advance: the method of execution, how the Jews would be taken to the ravine only after their possessions had been taken from them, and so on. All this is recounted as a series of practical problems solved by the officers in charge: Blobel, Jeckeln, and others, most of them historical figures (Paul Blobel and Friedrich Jeckeln were tried and

16. Ibid.

17. Garcin, "Littell est grand," 50. 
executed after the war). These men are shown worrying about the smooth functioning of the operation without asking themselves any other questions. Moreover, in this instance Aue must also narrate his own participation in the Aktion, for he is ordered to descend into the ravine and finish off those still alive after the mass shooting: "Pour atteindre certains blessés, il fallait marcher sur les corps, cela glissait affreusement, les chairs blanches et molles roulaient sous mes bottes. ... je m'enfonçais jusqu'aux chevilles dans la boue et le sang. C'était horrible" (To reach some of the wounded, one had to walk on the bodies, it was terribly slippery and the soft white flesh of the corpses rolled beneath my boots. . . . I sank up to my ankles in mud and blood. It was horrible) (125). One could see here an example of Littell's fondness for gore, but I think it is an example of the difference between fiction and history. A novel can allow itself, must allow itself, such detail if it is describing what happened at Babi Yar, where more than thirty thousand Jews were murdered in two days-and it is all the more striking when these details are recounted in the first person, by one of the murderers.

To be sure, Aue is not an ordinary murderer. After the narration, we have his reflections-again quite "invraisemblables" (unrealistic), and again necessary for Littell's project:

Même les boucheries démentielles de la Grande Guerre ... paraissaient presque propres et justes à côté de ce que nous avions amené au monde. Je trouvais cela extraordinaire. . . Notre système, notre Etat, se moquait profondément des pensées de ses serviteurs. Cela lui était indifférent que l'on tue les Juifs parce qu'on les haïssait ou parce qu'on voulait faire avancer sa carrière ou même, dans certaines limites, parce qu'on y prenait du plaisir.... Cela lui était même indifférent, au fond, que l'on refuse de les tuer, aucune sanction ne serait prise, car il savait bien que le réservoir des tueurs disponibles étaient sans fond.

[Even the demented butchery of the Great War ... seemed almost clean and just next to what we had brought into the world. I found that extraordinary.... Our system, our state, didn't give a damn about the thoughts of its servants. It didn't care whether they killed Jews because they hated them or because they wanted to advance their careers or even, within certain limits, because it gave them pleasure. ... It didn't even care, really, if some refused to kill them, they wouldn't be punished, for the system knew full well that the reservoir of available killers was bottomless.] (127)

This is a reality observed through the later analyses of Hannah Arendt on totalitarian systems or Christopher Browning on the role of "ordinary men" 
in mass murder. And it is made, fictively, by an SS officer who was in the ravine shooting people a few hours earlier. Unrealistic, no doubt, but powerful, and pointing not only to historical facts but to their ethical and moral implications.

\section{The Perpetrator as Moral Witness}

The minute one begins to reflect on the history of mass murder, one is necessarily drawn to ethical and moral questions: not so much why it happened but how it was possible for human beings to do this. In Les bienveillantes, questions about such moral implications arise when Aue speaks with other intellectuals involved in the killings. Littell's handling of these one-on-one conversations brings to mind André Malraux's novels, in which intellectual talk is a constant accompaniment to action. Like Malraux, Littell maintains extraordinarily rich exchanges of ideas in truly dialogical fashion, and many of these conversations revolve around "the Jewish question."

These conversations (including a memorable one between Aue and Otto Ohlendorf, another historical figure executed after the war, who calls the murder of Jews "une erreur . . . Mais une erreur nécessaire" [a mistake . . But a necessary mistake] [208]) occur throughout the novel; but they are especially frequent in the "Menuet" chapter. Just as the moral and historical center of the "Allemandes" chapter is the Einsatzgruppen killings, the moral center of the "Menuet" chapter is the camps. Here, too, Aue is an observer, but whereas in the Ukraine he had to participate actively in the killing, now he has a job that places him in tension with the killing mission, since he is charged with finding able-bodied prisoners for slave labor. Littell makes use here of a historical conflict in the SS ranks between those who (like Adolf Eichmann) wanted above all to "liquidate" the Jews and those (including, eventually, Himmler himself) who wanted to exploit able-bodied Jewish prisoners for the war effort before they became too weak to work. So the question was not whether these prisoners would die but simply when. Paradoxically, even though Aue remains in total complicity with the system, in his new job he is directed, by the system itself, to seek ways of "sparing" some Jewish prisoners from too harsh a treatment. This twist allows Littell to show Aue as being appalled and indignant at the treatment of the prisoners in Auschwitz without having to show the slightest sympathy for them as human beings (they are simply potentially useful labor) and without abandoning his Nazi allegiance. Moreover, as part of his job he has to have all the documentation on the camps, with several visits to see for himself how they function-whence his own continuing role as a reliable historical witness. 
But here more than ever, Aue's historical witnessing involves moral questions. Aue himself expresses shock when he first reads the statistics about the death rate in Auschwitz (this is the first time he hears of Auschwitz): "[Ces chiffres], je dois l'avouer, m'épouvantèrent" ([These numbers], I must confess, horrified me) (504). He decides to consult his constant friend Thomas Hauser, a kind of "double" who finds himself wherever Aue does. Hauser, a very clever, egotistical, totally amoral member of the SD, responds in a way that highlights his difference from Aue:

Il est remarquable à quel point les gens sont bien informés des prétendus secrets, le programme d'euthanasie, la destruction des Juifs, les camps de Pologne, le gaz, tout. . . Mais ce qui est encourageant, c'est que malgré tout les gens continuent à soutenir le Parti et les autorités, ils ont toujours foi en notre Führer. . . . Ce qui démontre quoi? Qu[e] . . l'esprit nationalsocialiste est devenue la vérité de la vie quotidienne du Volk.

[It's striking how much people know about the so-called secrets, the euthanasia program, the destruction of the Jews, the camps in Poland, the gas, everything. . . . But what's encouraging is that despite all that people continue to support the Party and the authorities, they still have faith in our Führer. ... Which proves what? [That] ... the National Socialist spirit has become the truth of the everyday life of the Volk.] (505-6)

Hauser's discourse here is a straight expression of Nazi fanaticism, without the least hint of moral scruple or even moral questioning; it also allows Littell to drive home the historical thesis that "ordinary" Germans knew far more than they later admitted about the fate of the Jews. Aue is far less straight than Hauser in his Nazi beliefs, even while remaining entirely within the system.

One apparent exception to the above is Aue's "fanatical" declaration about ethics in a conversation with Eichmann. When Eichmann, quite contrary to type, asks him whether Immanuel Kant's categorical imperative applies in wartime (after all, he says, we wouldn't want our enemies to do to us what we're doing to them!), Aue replies that there is no problem as long as one "rewrites" Kant's imperative as follows: "Agissez de manière que le Führer, s'il connaissait votre action, l'approuverait. ${ }^{18}$ Il n'y a aucune contradiction entre ce principe et l'Impératif de Kant" (Act in such a way that the Führer, if

18. Aue attributes this saying to Dr. Hans Frank, a jurist whom Hitler appointed governorgeneral of Poland; he was condemned to death at Nuremberg and hanged in 1948. 
he knew about your action, would approve of it. There is no contradiction between this principle and Kant's Imperative) (523). Eichmann seems satisfied, but a few pages later Aue remarks: "Et l'impératif kantien? A vrai dire je n'en savais trop rien, j'avais raconté un peu n'importe quoi à ce pauvre Eichmann. En Ukraine ou en Caucase, des questions de cet ordre me concernaient encore, je m'affligeais des difficultés et en discutais avec sérieux. . . Mais ce sentiment semblait s'être perdu. . . . le sentiment qui me dominait à présent était une vaste indifférence" (And the Kantian imperative? To tell the truth, I knew nothing about it, I had said pretty much what came into my head to poor Eichmann. In the Ukraine and in the Caucasus, I was still concerned with such questions, I was disturbed by their difficulty and discussed them seriously. . . . But that feeling seemed to have gotten lost. . . my predominant feeling at present was one of enormous indifference) (525-26). Despite his claim to indifference, however, Aue continues at this point to reflect and question himself. On his visit to Sobibor, he meets a perfectly ordinary fellow who has been gassing people ever since he was assigned to the euthanasia program in the late 1930s. Later this fellow was sent to Kharkov, where German soldiers who were too badly wounded were gassed in trucks. Compared with that, he says, Sobibor is easier. This meeting provokes a lengthy reflection by Aue, on whether what the Nazis did was "inhuman":

On a beaucoup parlé, après la guerre, pour essayer d'expliquer ce qui s'était passé, de l'inhumain. Mais l'inhumain, excusez-moi, cela n'existe pas. Il n'y a que de l'humain et encore de l'humain: et ce Döll en est un bon exemple. Qu'est-ce que c'est d'autre, Döll, qu'un bon père de famille qui voulait nourrir ses enfants, et qui obéissait à son gouvernement même si en son for intérieur il n'était pas tout à fait d'accord?

[After the war, to try and explain what happened, people talked a lot about the inhuman. But excuse me, the inhuman doesn't exist. There is only the human and more human: and this Döll is a good example of it. What is Döll, if not a good family man who wanted to feed his children, and who obeyed his government even if deep down he didn't completely agree?] (543)

Then he evokes the Americans and the British, who also committed their share of atrocities in their time and place. One could see this as an example of the Nazi tactic of self-justification by smearing the other. But because this is just a small part of what Aue tells us in this book, and since the great mass of what he tells us is his witnessing of German crimes, his accusation of the Americans and the British-and implicitly of "vous," the reader-has more force. 
What also has extraordinary force are some of Aue's conversations with other "thoughtful" Nazis, such as Eduard Wirths, the chief doctor at Auschwitz. Littell has Wirths expressing distress at the fact that many guards become sadists in the camp; a few pages later, he offers an explanation that may strike readers as improbable, coming from this Nazi doctor:

J'en suis arrivé à la conclusion que le garde SS ne devient pas violent ou sadique parce qu'il pense que le détenu n'est pas un être humain; au contraire, sa rage croît et tourne au sadisme lorsqu'il s'aperçoit que le détenu, loin d'être un sous-homme comme on le lui a appris, est justement, après tout, un homme, comme lui au fond, et c'est cette résistance, vous voyez, que le garde trouve insupportable, cette persistance muette de l'autre, et donc le garde le frappe pour essayer de faire disparaître leur humanité commune.

[I have come to the conclusion that the SS guard does not become violent or sadistic because he thinks that the prisoner is not human; on the contrary, his rage increases and turns sadistic when he realizes that the prisoner, far from being a subhuman as he was told, is precisely, after all, a man like himself, and it's that resistance, you see, that the guard finds unbearable, the other's mute resistance, and so the guard beats him to try and eradicate their common humanity.] (575)

This insight, which contradicts Nazi doctrine about the victims' lack of humanity and affirms instead the victims' "mute resistance" as human beings, strikes one as more likely to be found in the pages of L'espèce humaine (The Human Species), Robert Antelme's philosophical memoir on his camp experiences, than in the mouth of a man who has gone down in history as one of those responsible for the deaths of several million people in the gas chambers. ${ }^{19} \mathrm{We}$ could see Littell's maneuver here as a kind of ironic last laugh, making a very unlikely personage the source of a philosophical truth, or Littell could be making use here of Wirths's reputation as a "humane" doctor, despite his horrific role in Auschwitz. In either case, the truth of Wirths's insight gains even more weight coming from him. In a way, we could see Wirths as a historical counterpart to the fictional Aue: a Nazi ideologue who never refused to obey the system but nevertheless retained a certain humanity and moral sense.

19. Wirths was responsible for the medical selections of prisoners for extermination and also oversaw numerous experiments on prisoners; at the same time, he has been described as a man of conscience, terribly conflicted about his role in Auschwitz. Imprisoned after the war, he committed suicide while awaiting trial. For a full discussion, see Robert Jay Lifton, The Nazi Doctors: Medical Killing and the Psychology of Genocide (New York: Basic Books, 1986), chap. 18. 
"Yes, but," one could ask, "doesn't this make the fictionalized Wirths in Littell's novel appear troublingly appealing?" Probably it does. And the same "appealing" quality exists in the fictional Aue as well. That is the price Littell pays (and the reader pays?) for using Aue as a moral witness. It is as if one cannot have it both ways: either Aue must be totally fanatic and amoral (not inhuman, just fanatic and amoral, like his friend Hauser) but then unable to engage in reflections that carry moral weight, or he is at least a partly reliable moral witness-despite himself, as it were-concerning Nazi atrocities, but then he cannot be totally fanatic and amoral. The choice to accord him a certain degree of moral awareness is similar to Littell's earlier choice to entrust him with the telling of historical truth.

At some moments, Aue's tone is coldly analytic, as if he were a critical but detached observer of the Nazi machine. He comments, for example, on the Nazi bureaucracy's use of language, especially the Nazis' preference for passive constructions: "Ainsi les choses se faisaient toute seules, personne ne faisait jamais rien, personne n'agissait, c'étaient des actes sans acteurs" (Thus things got done all by themselves, no one ever did anything, no one acted, these were actions without agents) (581). Or there is his lengthy commentary, very much inspired by Arendt and other historians and philosophers, on why the Nazis "obstinately" sought to exterminate the Jews of Hungary as late as 1944, when by purely rational calculations they should have expended their energies elsewhere (717-19). At other times, his comments become more subjective. In one sequence, he accompanies Albert Speer on a hunt (without carrying a gun himself, because he does not like to kill, he says), and while they are walking through the woods, he is beset by unpleasant memories despite the beauty of the place: “Une bouffée d'amertume m'envahit: Voilà ce qu'ils ont fait de moi, me disais-je, un homme qui ne peut voir une forêt sans songer à une fosse commune" (A wave of bitterness washed over me: Here is what they've made of me, I said to myself, a man who can't see a forest without thinking of a mass grave) (645). This is a rare moment when Aue seems to set himself against the system, against "them," as indicated by the contrasting pronouns ("ils ont fait de moi"). Everywhere else, whatever historical or moral distance from the system he may manifest exists simultaneously with his unconditional allegiance to it.

This structure of simultaneous belonging and distance, so that Aue is at once wholly within the Nazi system and sufficiently outside it to see it for what it is, both historically and morally, is what defines his particular status as a perpetrator-witness. I believe that it is Littell's major achievement in this novel. 
And it is a literary achievement, for Aue is hard to imagine as an actual person; he is even hard to imagine as a "believable" character in realist fiction. ${ }^{20}$

As it happens, the structure of simultaneous but contradictory states that characterizes Aue as narrator also defines the psychological phenomenon of dissociation or splitting, whereby one part of the psyche "knows" something that another part denies. And that brings me to what I earlier referred to as a problematic aspect of Littell's book.

\section{The Perpetrator as Incestuous Matricide?}

Interspersed with Aue's historical and moral witnessing is Aue's personal history, told and recalled in fragments. The son of a German father who fought in World War I and later abandoned his family, and an Alsatian French mother who took up with a Frenchman after her husband's disappearance, Aue grows up as a "disturbed" adolescent. He cuts off all contact with his family after around age twenty and chooses to live in Germany as a sign of allegiance to his father; furthermore, he is in love with his twin sister and has had incestuous relations with her; and finally, while on a convalescence leave after receiving a serious head wound at Stalingrad, he murders his stepfather with an ax and strangles his mother. He has absolutely no memory of these acts and never acknowledges them.

Here, then, is the problem: what does this private story straight out of Aeschylus, but with a good modern dose of erotic transgression à la Georges Bataille, do to the public history of war and genocide that Aue is assigned to narrate and analyze? Littell has explained in interviews that he felt he really "had" the book when he got the idea of drawing on the Oresteia for its plot structure. ${ }^{21}$ Although Aue's personal history occupies far fewer pages than those devoted to the war and the genocide, the importance of the Oresteia plot

20. This may seem to contradict my earlier comment on the Nazi doctor Wirths's conflicted feelings about his actions, but Aue is far more explicit and prolific in his analyses and his moral witnessing than Wirths ever was (at least according to what is known about him), so in fact the comparison confirms Aue's fictional status. If the historical Wirths was conflicted about his role as the chief of a killing factory, that is a far cry from Aue's (or rather Littell's) work of witnessing and analysis in this novel.

21. See, e.g., the interview with Florent Georgesco in La revue littéraire, no. 28 (2006), rpt. as "Jonathan Littell: 'Maximilien Aue, je pourrais dire que c'est moi,", Le Figaro Magazine, December 30, 2006, 48-52. Florence Mercier-Leca makes a strong case for the use of the Greek myth in the novel, as one of many texts that constitute its intertextual web, in "Les Bienveillantes et la tragédie grecque: Une suite macabre à L'Orestie d'Eschyle," Le débat, March 2007, 45-55. While I am persuaded by her general argument, I still find the coexistence of the "private" plot with the historical account problematic - or at least, problematic enough to be examined critically. 
is indicated by the novel's title (Les bienveillantes is a literal translation of Eumenides, the euphemistic name assigned to the Furies after they have been mollified). Significantly, this word also appears in the novel's last sentence: "Les bienveillantes avaient retrouvé ma trace" (The kindly ones had picked up my trail) (894).

Let me briefly indicate the questions that bother me. On the one hand, there is the problem of the "memory hole." Aue, who remembers the tiniest details of what he felt and saw and said to others in the forests of the Ukraine, in Stalingrad under siege, in Berlin under Allied bombing, or as he stood on the arrival platform at Auschwitz, remembers absolutely nothing of the murders he committed in his mother's house in Antibes. His gruesome double killing is accomplished in the ellipsis between two sentences: "Je me couchai et m'endormis. Lorsque je me réveillai la lumière avait changé, il faisait très sombre" (I lay down and went to sleep. When I awoke, the light had changed, it was very dark) (487). When he discovers the two bodies, his reaction is one of horror and anguish: "On l'a étranglée, on a étranglé ma mère. . . . L'assassin avait dû d'abord tuer Moreau, puis monter" (She was strangled, my mother was strangled. . . . The killer must have killed Moreau first, then gone upstairs) (489). This is a textbook case of dissociation, very well done by Littell. Right to the end, Aue never "remembers" the action he committed; it is the two somewhat comical detectives, Weser and Clemens, who figure it out, by the usual methods of evidence gathering and deductionmethods similar to those of the historian, incidentally. ${ }^{22}$ But if Aue himself never recalls his act, how can we grant him-even fictively-the ability to recall and reliably report on the events in Kiev, Stalingrad, and other cities? Does his private memory hole undermine the project of historical witnessing that is the novel's major achievement?

On the other hand, for Aue to continue with his life after the killing as if nothing has happened (which he does here) and to have a memory of his act would be an even greater undermining of the historical project. For if he continued to function in the full knowledge of what he had done, he would have to be truly monstrous, and that in turn would destroy his status (however

22. Mercier-Leca suggests that the novel casts doubt on whether Aue actually did commit the murder ("Les Bienveillantes et la tragédie grecque," 49-50), but the case made by the detectives seems airtight, since Aue's bloody clothes are found in the bathtub of the house where the murder is committed. Is Littell playing here with the whole question of the reliability of evidence and the reconstruction of historical fact? Whether he is or not, I think it would actually weaken the private plot if the reader doubted that Aue had committed the murder. It would also weaken the historical narrative by casting doubt on the possibility of ever reconstructing a veridical account of the past. 
problematic it may appear even now to some readers) as a historical and moral witness. By having Aue-at least the conscious, narrating Aue-remain dissociated from his act to the very end, Littell can preserve him as a reliable witness to the Holocaust, even while his memory hole about the family murder demonstrates the human ability to block out unbearable actions.

This could, then, be a plausible literary justification for the memory hole. However, there is another question: why did Littell, as novelist, feel it necessary to have his protagonist commit such a heinous act in the first place? Aue is, willy-nilly, a representative figure-one of the many German intellectuals who willingly participated in the Nazi machinery of destruction. His intelligence, his self-questioning, and above all his pitiless detailing of the machinery in which he was involved make of him an exemplary figure, even if one lacking in verisimilitude; as I have tried to show, that lack is a strength of the novel, not a weakness. But what do Aue's incest and matricide do to his exemplariness? Is Littell suggesting that all, or at least many, intellectuals who joined the SS had some grave family dysfunction to explain their behavior? ${ }^{23}$ Or is Aue's small but crucial critical distance from the system he describes due, at least in part, to his sexual oddity, so that his absence of "straight" Nazi fanaticism is mirrored by a similarly "nonstraight" sexuality? But even if that is the case, doesn't the very extremeness of Aue's family story take away from his authority as a witness to the Holocaust?

I am still struggling with these questions. It occurs to me, however, that one could read the two stories - the public history and the family tragedy-in counterpoint, without looking for causal connections between them. The two stories would then be related metaphorically, not logically or psychologically in terms of cause and effect. The metaphorical equivalence would hinge on the question of guilt and responsibility. Although Aue claims from the start that he feels no remorse for his wartime activities, the novel's last sentence

23. Interestingly, several years before publishing Les bienveillantes, Littell wrote a short book in which he did a close reading of a work by the Belgian fascist leader Léon Degrelle, who fought on the German side on the Russian front and survived to tell the tale (Le sec et l'humide: Une brève incursion en territoire fasciste [Paris: Gallimard, 2008]). Littell explains that he was seeking to "test" on Degrelle the theoretical model of the "male soldier" proposed by Klaus Theweleit, in his important book Männerphantasien (Male Fantasies) (Frankfurt am Main: Verlag Roter Stern, 1977), which was based on the writings of an earlier generation of German soldiers, members of the Freikorps after World War I. Although Littell did not strictly retain Theweleit's model (which emphasizes the fascist hatred of the female body and of all that is "soft" or "humid") in constructing the figure of Aue, he was obviously influenced by Theweleit's notion that fascism had to be envisaged in "corporal" terms as much as in terms of adherence to an ideology. Significantly, he makes Aue's father a member of the Freikorps. 
("Les bienveillantes avaient retrouvé ma trace") suggests that he continues to be pursued by the Furies for his matricide. Littell has explained in interviews that what he likes about Greek tragedy is its attitude toward guilt and responsibility: it does not matter whether the one who commits a crime intended it, or remembers it, or even knew what he or she was doing. Oedipus murdered his father and married his mother, in full ignorance-yet he is judged guilty, by himself as well as others. ${ }^{24}$ The family plot in Les bienveillantes is there, perhaps, to remind us that it is the action that defines guilt in crimes against humanity, not the intention behind it: all those who participated in the Nazi system of extermination were guilty of the crimes it committed, independently of intention, and even of memory. 
